\title{
The Mongolian Scholars' Interpretation of the Cultural Origin of Some Mongolian Epic Motifs and Plot Types
}

\author{
Si Qintuoya ${ }^{1}$ \\ ${ }^{1}$ School of Mongolia Studies, Inner Mongolia University, Hohhot, Inner Mongolia, 010021.
}

Keywords: Mongolian scholar; Mongolian epic; motif; plot type; cultural origin

\begin{abstract}
In the Mongolian epics, the motif is the unit of repetition with high repetition rate. The classification of the Mongolian epic motifs according to the plot type can be very helpful in understanding the cultural origins of the episodic types in the Mongolian epic. This paper aims at the interpretation of Mongolian scholars on the cultural origins of some Mongolian epic motifs and episodic types.
\end{abstract}

\section{Introduction}

The classification of the Mongolian epic motif started with Teger Burzanov and was divided into eight elements. That is (1) start;(2) unfortunate encounter, looking for fixating wife;(3) expedition, the father to support their children to find wife; (4) defeat the road of misery; (5) victory to protect their hometown; (6) eliminate the disaster, to find the betrothed wife;(7) return;(8) feast. Famous German scholar W Hercynian conducted an in-depth study of the classification of the Mongolian epic motifs and classified the Mongolian epic motifs in a more detailed and definite manner, raising the study of the classification of the Mongolian epic motifs to a new level. Professor Bao Yin and Professor Siegel also put forward their unique opinions on the classification of Mongolian epic motifs.

\subsection{Use a Fire Sickle to Take the Fire and Burn Dead Goose's Body Mottos}

Epic blood is the power of regeneration, above the blood can be resurrected, so the body burned, scattering ashes, the purpose is not to let him (it) rise. [1]

\subsection{The Theme of Sub-body}

Punish unfaithful wives, daughters, and unfaithful servants by adopting the method of "four horses dividing their bodies" or chopping mud. This punitive approach is strikingly similar to the way in which such people are disposed of throughout Europe, in contrast to the Chinese's delaying tactics and the method of dismemberment of criminals. [1]

\subsection{Sarcophagus or Stone Grave Mouth Motif}

In the Neolithic tombs, the dead sarcophagus was placed straight into a hole drilled in a boulder to prevent the resurrection or escape of the soul. The pythons in Mongolian ephemera use stones to cobble together wounds or are buried beneath large stones. [1] The stone pressure on it, you can prevent pythons ran out. Inheritance of this culture, it has become a custom.

\subsection{The Hero Motif}

There are a lot of heavenly spirits in the motif of the birth of heroes. Some heroic rocks burst and some heroes are born. Some parts of the body are made of iron, stone, copper and other metals. A systematic study of the few recorded hymns of Shaman in Mongolia reveals that the birth of certain mountain gods is similar. [2]

\subsection{The Epic Horse Motif and the Story of the Horse Motif}

The story of Martin Bu function, can become stars, birds, flies. In addition to the roll to become horses; can give the owner a name; to create the owner of the people and livestock; can hint 
destined fiancee; can prompt the difficulty of the road and teach the master to overcome the difficulties; can revive holy water Master; Rescued Master from Tamu with his own tail. The epic horse loses the character of the magical story. Although it is still the master's assistant, it understands the master's language and speaks by himself. Tears indicate the imminent danger. [2] In the first Mongolian history and literature monumental "secret history of Mongolia" and the "Mongolian secret history" historical and literary traditions of a series of successive works, the first chapter of Mongolian historical novel "Green Romance," and even modern works of Mongolian writers manifests the motif. As can be seen, this motif constitutes a traditional and important motif in Mongolian narrative literature.

\subsection{Lion Motif}

Everything in the epic that does not belong to Lamaism also does not necessarily originate from Tibetans. Except those directly come from India, there are some motifs generating indirectly from Buddhism in Central Asia. Some of the foreign folklore, especially Iranian-folklore, came to Tibet soon after they were accepted here. For example, consider a lion as the first animal to rule nature and represent a glacier in the mountains. The ancient Tibetan customs transformed all kinds of legendary lioness into small lions in the image of Milarepa. However, even if ancient times existed in Tibet, it is safe to say that it is from Iran. The new year marking Iran emphasizes the jumping of the lion dance and the cold water to a group of nude children running. Such festivals and customs came to China through Central Asia. But the second habit, the custom of watering naked children, did not exist in China about the 10th or the 11th century, leaving only the lion dance alive today, both preserved in Tibet for this complexity, Gesar has the title "Great Lions" in the world. The birth of heroes is supernatural, similar to lion cubs in Snowy Mountains. [2]

\subsection{On the Twelve Figures}

The traditional view is that "Jiang Geer" consists of twelve poems, because there are twelve male heroes in the epic. In the "Jiang Geer" epic, the symbolic number of "Twelve" appeared 90 times. There are always 12 "men" or "knives" around Jang Geer. Often use "six thousand and twelve men," such a number of words. Digital symbols often play an important role in the oral literature of many Eastern peoples, especially the nomadic peoples. In many Central Asian nations, the "12" figures are associated with the 12 months of the lunar calendar, with 12 animal species dating. [2]

\subsection{The Omen before the Birth Motif}

In the epic of Central Asia Minor Turkic peoples, painful crying results in the fulfillment of the aspirations and the birth of their sons. Most of God's promises are prayers, incense, dreams, or the appearance of the Saints' House of Hi. Xi Zi Lou turned himself into a wise old man or grandmother, who told him desperate to have a son. For example, in the epic poem "Elttork", Elleman elderly and his wife went to the cemetery Baja Eddin's cemetery to go pilgrimage. There, the sages listened to their petitions. At night, Ellerman met the holy man, he turned into a 90 -year-old man wearing a headscarf, handed him an apple to eat him. Sage told him later gave birth to a son, son named Tuote Turk.

Obviously, this promised theme carries the symbol of Islam. Alghero Chagan Eugan, one of the few Mongols in his epic poem involving a sonless hero, is one of them, an unregulated rainbow and a burning wildfire, declared to be the birth of his son Omen. In the Altaic Turkic epic "Good Poodu" is a tree-parked bird listening to the miserable life of Qara attu Qan, who comforts him and promises he will receive Longing son. [2]

\subsection{Married Mother from Motif in Different Places}

Once the hero subdued his enemy, he set out on a long and arduous expedition to find the heroine living in the distance as his own fiancée. This reflects the common customs of nomadic and interracial marriages between Turks and Mongolia. [2] The ancient Mongolian people had a marriage taboo, not inter-clan,men can only marry his tribe woman. Women married to this clan can never be separated from this clan. If husband died, only remarry her husband's close relatives. The 
old days, the groom married, will have to wear saber and bow and arrow.

\subsection{The Owner Becomes a Poor Herdsman, the Horse Becomes Covered with Psoriasis Pony Motif}

They may interpret this motivation as an attempt by singers (singers) to express themselves. Like Turkic singers (singers), Mongol singers (singers) are mostly poor shepherds who neither read nor write. Perhaps he wants to show here that a man of humble origin can also reach some glitz that gives hope to his own state of affairs. In the Turkic fairy tale bald, the content of "poor young herdsmen" was supplemented by the fate that he was married to a princess. Shepherds are often chosen as kings in Uzbek's fairy tales. [4]

\subsection{Respect the Mountains, Worship God Mother}

An extremely important task in the study of epics is to continue arguing the conjecture about the connection between the Epic and the Shamanic respect of the mountains and the worship of the idea of a mountain God, possibly derived from the Stone Age. In Inner Mongolia, stone heap is very common, called Obo. Popular folk song "obo meet" sing is the Mongolian youth dating in the obo story. Obo is Mongolian, ancient literary transliteration Bo. "Piling Yi Yi", refers to the base stone sacrifice God, and ancient Mongolian community worship mountain worship, praying for the auspices of the tradition related to "worship prayer Piles of stone phosphorus, mountains absolutely plug can always God, but shocking rain should be like a ring"the poem spread in the world [4].

\subsection{The Soul of the Enemy into Animal Motif}

The content of Mongolian epics still can not determine the source of most of Mongolian epic according to the current research level. However, some epic can be traced back to more ancient sources and can be found with ancient documents such as those dating back to Indian and Tibetan literature, that is, we can find a reference to the works of Indian and Tibetan literature. [2]

\subsection{A Contemptuous Young Man Motif}

The heroic turn into a humble, nasty youngster who appeared as a suitor in Khan's court and was laughed at by all is clearly symbolic and educational. Mongolian singers explain to the audience through the story of the transformation of heroes that they should not be judged on the form of appearance but on the nature of the person as the youngest princess does. [5] This motif mainly plays a guiding role in the moral character, we must know how to look inside.

\subsection{Recover the Bull's Motto}

Heroes are not captured in mythological animals, because the knight herdsmen do not believe in the mythology of animals, but the natural tradition and reality together. Obviously, knights and nomadic peoples, based on their accumulated experience, know that only animals that have escaped to the grassland of other tribes can get back their weapons. Members of other tribes may consider such a thing as banditry. Of course, this behavior requires people to carry out a small fighting spirit. 6]

\subsection{Catch the Animal or Behemoth Motif}

Now we come back to the test of the mission-accomplished nature in heroic odes. To be sure, in general, such a mission is always associated with killing the animal and bringing it back to Khan's courtyard. Remove the dragon (probably Kelpolot) and Phoenix, as well as wild horses, wolves and other animals. Clearly, the carols of Lin's inhabitants are closer to mythology than the heroic nomadic herds of the prairie. Assuming that at least we think the epic poems in Central Asia are derived from mythology, then it should be affirmed that those mythic animal figures and missionary carols are all ancient parts of the heroic caricature of Central Asia's epics. Only this department still preserves some forgotten ancient myths and even makes us clear at a glance. [6] 


\subsection{Start the Motif}

The beginning of the epic has a lot in common with the stories and legends. The common ground is that the content of the story takes place, the times try to go up, the sooner the better. The difference is that epic poetry, unlike tales and legends, is always said (very early, very old and ancient) when compared with the formation of the universe, celestial bodies and landscapes, the birth of Buddhas and ancient historical figures. This metaphor has produced abundant metaphors in different social systems and cultural backgrounds in the long circulation process. For example, the ancient metaphor is similar to the shamanic phrase, and the universe was created after Buddhism and Buddhism mythology. [6]

\subsection{Kill Python Guus Motif}

A Typical Motif in Mongolian Epics. You can categorize five motifs. Defeat soul and body motif Actual power combat kill motif,Magic or treasure to kill the motif. Seize the mysterious place to kill the enemy motif.Federal enemies kill their loved ones motif.In the heroic epic of Mongolia, a warrior kills a pythonic demon and burns its bones, then digs a sixty-inch-deep black hole and throws it into a deep cave, where it is crushed with boulders. This is a typical Shamanistic town ghost ceremony. [5]

\subsection{Crossed the Archery Hit in the Disabled, the Revival of the Motif}

Professor Hercynian "on the resurrection of the dead mothers," a text, the Mongols used to resurrect the deceased were used as follows: a collection of bones, as a bones, spanning three times, flash segment of silk, three call three volumes, whip three times, puffing, spa, kick, read three times, medication, spit three times, across the body three times and so on, and across the body three things interpreted as "the woman across the body is the mother of the regenerated dead." [3] (P190) Professor Poin and Professor Siegel named the motif "the motif of the handicapped across an archery hit" and explored the origin of the motif, arguing that the ancient Mongolian woman's sacredness Respect and worship, the result of worship. [6]

\subsection{The Palace Motif}

W. Hercynian in the classification of the Mongolian epic motif, the heroic palace and the python Gus Palace two major palace motif [2]. The Bubo School also put forward a similar motif in his "Mongolian epic towns". (CENTRAL ASIATIS JORNAL "25, 1981, P89-93) Poin and Siegher regarded the hero's palace motif as a part of the study of epic poetry and art that can not be neglected, and proposed the Mongolian-like palaces, cottage-like palaces and God conceived the idea of changing the palace and other three motifs. ("Palace of Mongolian epics", Inner Mongolia University Journal 1988.1)

\subsection{Cyclops Motifs}

As we have pointed out, the Cyclops plot in the Odyssey can also be seen in some of Buryat's epics, the Cyclops motifs appearing in different Epic Turks. [2] Hao ancient race with the Cyclops story, in addition, the world knows all the Greek mythology Cyclops Polyphemus. In Greek myths and legends, the Cyclops have an unusual origin.

\subsection{The Hero into a Contemptuous Guy Motif}

The hero into a humble, nasty young man appeared as a suicidal court in Khan's court and was ridiculed by everyone, which obviously has some kind of symbol and education significance. Mongolian singers explain to the audience through the story of the transformation of heroes that they should not be judged on the form of appearance but on the nature of the person as the youngest princess does. [2]

\section{Conclusion}

To sum up, although the epic details are rich in the Mongolian epic motifs, what is expressed in 
essence is some generality of the epic structure, and the type of emotion is one of the important contents. Changes in the emotional details of the local epic text are reflected in the real local motif exists, and in a particular region will produce changes in Central Europe. The paper has a total of 21 kinds of motifs, and interpreted its cultural origins.

\section{References}

[1] W. Hercynian: "The Historical Authenticity of Mongolian Heroic Epic", "Mongolian Studies" 1988.3.

[2] Institute of Chinese Literature, Chinese Academy of Social Sciences, "The Collection of National Literature," the first episode, 1983.

[3] Institute of Chinese Literature, Chinese Academy of Social Sciences, "second chapter of the collection of national literature," 1984.

[4] Po Yin and Segar: "The beginning of Mongolia's epic motif," Inner Mongolia University Journal 1986.2

[5] Po Yin and Segar: "The Motif of Killing the Enemy of Python in Mongolian Epics", Journal of Inner Mongolia University 19869.4

[6] Po Yin and Segar: "on the epic" Jiang Geer "in the archery was hit the disabled mothers", "Mongolia", 1999.2 